\title{
PENGEMBANGAN BIG BOOK UNTUK PENGAJAR BAHASA INGGRIS DI SEKOLAH TERPENCIL
}

\author{
Nine Febrie Novitasari ${ }^{1}$, David Nurfiqih ${ }^{2}$ \\ ${ }^{1}$ Universitas Abdurachman Saleh, ${ }^{2}$ SMP Negeri 1 Asembagus \\ ninefebrie@gmail.com ${ }^{1}$
}

Received: December 14, 2020 Revised: December 15, 2020 Accepted: December 19, 2020

\begin{abstract}
ABSTRAK
Bahasa Inggris sudah mulai diperkenalkan di tingkatan sekolah dasar walaupun posisinya hanya sebagai mata pelajaran muatan lokal. Hal ini dikarenakan sekolah-sekolah di daerah terpencil tidak memiliki guru yang dapat mengajar mata pelajaran Bahasa Inggris. Namun di banyak sekolah terpencil, sering ditemukan masalah seperti tidak adanya pengajar Bahasa Inggris terlatih dan media ajar yang mendukung. Masalah-masalah ini juga ditemukan di SD Negeri 6 Tambak Ukir Kecamatan Kendit Kabupaten Situbondo. Pembelajaran Bahasa Inggris di sekolah tidak maksimal karena tidak adanya media ajar Bahasa Inggris. Solusi untuk menjawab permasalahan tersebut adalah dengan mengembangkan media ajar big book. Tampilan big book yang penuh warna dan menarik membuat siswa lebih tertarik untuk belajar. Maka dari itu, tujuan penelitian ini adalah untuk mengembangkan big book sebagai media ajar alternatif yang dapat dipakai untuk mengajar mata pelajaran Bahasa Inggris di SD Negeri 6 Tambak Ukir. Model penelitian dan pengembangan (research and development) yang dipakai diadaptasi dari model Gall dkk (2003). Ada empat tahap dalam proses pengembangan ini yaitu analisis masalah, pengembangan produk, uji coba produk, dan revisi produk. Hasil akhir dari pengembangan ini adalah poduk pendidikan, yaitu sepuluh big book dengan beberapa jenis tema dilengkapi dengan petunjuk penggunaan. Instrumen yang dipakai dari tahap awal ampai akhir adalah kuesioner, petunjuk evaluasi media ajar, lembar observasi, dan pedoman wawancara. Hasil dari penelitian ini adalah satu set big book dengan tema: numbers, letters, body parts, farm animals, colors, greetings and leave-takings, family members, occupations, playground, dan narrative. Setelah melalui tahap validasi dan uji coba, big book ini terbukti valid, efektif, dan praktis.

Kata kunci: bahasa Inggris, big book, SD Negeri 6 Tambak Ukir
\end{abstract}

\begin{abstract}
English has been introduced at the primary school level even though its position is only as a local content subject. This is because schools in remote areas do not have teachers who can teach English subjects. However, in many remote schools, problems are often found, such as the absence of trained English teachers and supporting teaching media. These problems are also found in SD Negeri 6 Tambak Ukir, Kendit District, Situbondo Regency. Learning English in schools is not optimal due to the absence of English teaching media. The solution to answer this problem is to develop the big book as an alternative teaching medium. The colorful and attractive appearance of big book makes students more interested in learning. Therefore, the aim of this research is to develop big books as an alternative teaching medium that can be used to teach English at SD Negeri 6 Tambak Ukir. The research and development model used was adapted from the Gall et al. (2003) model. There are four stages
\end{abstract}


in this development process, namely problem analysis, product development, product testing, and product revision. The result of this development are ten big books with several types of themes equipped with instructions for use. The instruments used from the beginning to the end were questionnaires, instructional media evaluation instructions, observation sheets, and interview guides. The results of this study are a set of big books with the themes: numbers, letters, body parts, farm animals, colors, greetings and leave-takings, family members, occupations, playground, and narrative. After going through the validation and testing stages, the books have proven to be valid, effective, and practical.

Keywords: big book, English, SD Negri 6 Tambak Ukir

\section{PENDAHULUAN}

Pengenalan keterampilan berbahasa Inggris dapat dilakukan sejak anak berusia dini karena anak sedang berada pada masa critical age, masa paling peka untuk belajar bahasa. Selain itu, banyak orangtua yang menginginkan anaknya memiliki keterampilan berbahasa Inggris sejak dini dengan harapan anak memudahkan kehidupan mereka di masa depan. Penguasaan Bahasa Inggris pada anak sejak usia dini akan membantu mereka menjawab tantangan dunia modern, seperti kemudahan dalam mengakses pekerjaan dan teknologi (Maili, 2018).

Bahasa Inggris menjadi salah satu mata muatan lokal yang diajarkan di tingkat sekolah dasar. Bahasa Inggris ditetapkan sebagai muatan lokal dikarenakan sifat dari materi yang hanya berupa pengenalan dasar, yaitu menekankan pada perbendaharaan kata. Namun, sekolah memiliki kebijakan untuk mengembangkan materi sesuai dengan kondisi siswa dan lingkungan masing-masing. Pada Kurikulum 2013, mata pelajaran bahasa Inggris bukan merupakan mata pelajaran wajib dengan beberapa banyak pertimbangan, salah satunya adalah kurangnya tenaga pengajar Bahasa Inggris di daerah terpencil. Sekolah boleh tetap memberikan mata pelajaran bahasa Inggris atau bahkan meniadakannya.

Sebagai muatan lokal, Bahasa Inggris hanya diberi alokasi dua jam/minggu. Musliar dalam Afifah (2012) mengatakan bahwa dikarenakan posisi Bahasa Inggris yang hanya sebagai mata pelajaran muatan lokal, maka sekolah tidak boleh tidak menaikkelaskan/meluluskan siswa yang nilai Bahasa Inggrisnya tidak melewati KKM.

Menurut Hartin (2017:2), pembelajaran bahasa Inggris untuk sekolah dasar merupakan upaya membangun dasar sumber daya manusia berkualitas. Keberadaaan mata pelajaran ini tidak boleh dianggap remeh atau masih dianggap lebih penting dari pelajaran lainnya walaupun posisi mata pelajaran ini adalah sebagai mata pelajaran muatan lokal atau tambahan. Peran dan fungsi sekolah dalam hal ini yang dapat memposisikan mata pelajaran Bahasa Inggris sebagai mata pelajaran unggulan sangat penting. Sayangnya, Bahasa Inggris 
sering ditetapkan menjadi muatan lokal di sekolah tanpa memperhatikan siapa yang akan menjadi pengajarnya. Di tingkat sekolah dasar, banyak ditemukan guru yang mengajarkan Bahasa Inggris tanpa latar belakang pendidikan atau pelatihan dalam pembelajaran anak-anak secara umum atau lebih khusus pembelajaran Bahasa Inggris bagi anak-anak (Copland et al, 2014). Moon (2005) menyebutkan beberapa kompetensi yang harus dimiliki oleh pengajar Bahasa Inggris bagi anak-anak:

a. pengetahuan dan kelancaran berbahasa Inggris (termasuk keterampilan yang baik dalam komunikasi di kelas) dan pengetahuan tentang budaya,

b. pedagogi bahasa asing (pengetahuan dan strategi yang tepat untuk pembelajaran bahasa asing bagi anak-anak),

c. pengetahuan/pemahaman tentang perkembangan anak.

Namun, faktanya proses pembelajaran Bahasa Inggris pada anak usia ini cukup rumit karena butuh penanganan yang berbeda dibandingkan dengan pembelajaran Bahasa Inggris pada orang dewasa. Selain itu, tidak semua anak memiliki minat untuk belajar Bahasa Inggris, dan terlebih lagi, sebenarnya tidak ada alasan yang menguatkan dan memberi cukup bukti tentang pentingnya/urgensi pembelajaran bahasa Inggris sejak usia dini. Hal ini didukung oleh pernyatan Singleton (2013) mengatakan bahwa memberikan anak bekal keterampilan berbahasa asing tidak menjamin bahwa mereka akan berhasil dalam proses pembelajarannya. Lebih jauh lagi, proses pembelajaran bahasa asing pada anak-anak tidaklah mudah karena mereka memiliki karakteristik tersendiri terkait dengan proses pembelajaran bahasa:

a. Semakin muda usia anak, semakin mereka tidak memiliki alasan mengapa mereka butuh belajar bahasa asing. Bahkan mereka tidak mengerti apa dan bagaimana itu belajar bahasa. Jadi untuk pengajar bahasa Inggris untuk anak-anak, tugas terpenting adalah memotivasi dan menciptakan suasana yang menarik minat anak sehingga mau mencoba belajar dan menggunakan bahasa.

b. Karena usia yang masih sangat muda, anak-anak masih berada dalam proses perkembangan. Mereka masih belajar bagaimana mengatur perilaku dan perasaan. Anakanak bisa saja tiba-tiba tidak berminat lagi pada apa yang sedang dikerjakan karena rentang perhatiannya sangat pendek. Remaja atau orang dewasa mungkin akan mengatakan pada pengajar bila mereka bosan melakukan sesuatu, namun tidak dengan anak-anak.

c. Anak-anak juga lebih memperhatikan arti situasi daripada arti kata/kalimat. Insting alami anak-anak dalam situasi apa pun adalah memahami situasi tersebut. Saat mereka melihat 
sesuatu, seperti menonton film, mereka akan mencoba memahami isi cerita melalui apa yang mereka lihat, misal ekspresi wajah, gerak tubuh, tempat, atau membandingkannya dengan pengalaman mereka di masa lalu yang mirip dengan apa yang mereka lihat saat itu. Mereka tidak akan memperhatikan kata atau kalimat apa yang digunakan pada situasi tersebut.

d. Sejak lahir anak-anak memiliki insting kuat untuk menjelajahi lingkungannya. Hal ini ditunjukkan dari kegemaran mereka menyentuh dan bermain-main dengan benda di sekitarnya, seperti menekan-nekan tombol tertentu, melempar-lempar bola, atau mencoret-coret dengan pensil. Jika ini dikaitkan dengan pembelajaran bahasa, kegiatankegiatan tersebut mendukung perkembangan kognitif anak.

Maka dari itu, jika tetap ingin membekali anak dengan keterampilan berbahasa Inggris sejak dini, proses pembelajaran yang menyenangkan adalah syarat utama yang harus ada. Salah satu faktor yang dapat membantu membuat proses pembelajaran Bahasa Inggris menyenangkan adalah dengan adanya media ajar yang tepat. Media ajar Bahasa Inggris bagi anak sekolah dasar sebaiknya dirancang untuk membantu siswa belajar perbendaharaan kata baik secara lisan maupun tulisan. Sehubungan dengan hal tersebut, media ajar bahasa Inggris yang bisa digunakan adalah media yang mampu mengenalkan siswa pada perbendaharaan kata dasar seperti flashcard, gambar bercerita, video animasi, majalah, komik, scrabble, dan poster. Namun sayangnya tidak semua siswa sekolah dasar beruntung memiliki akses terhadap media-media tersebut. Siswa yang lokasi tempat tinggal dan sekolahnya jauh dari perkotaan akan mengalami kesulitan untuk belajar menggunakan media-media tersebut. Harga media yang tidak murah juga menjadi faktor penghambat kurangnya kesempatan bagi siswa di sekolah-sekolah tertentu untuk belajar Bahasa Inggris dengan lebih maksimal.

Permasalahan ini juga ditemui di sekolah SD Negeri 6 Tambak Ukir. Letak sekolah yang jauh dari kota membuat akses siswa terhadap fasilitas umum sangat terbatas. Bacaan dan media ajar Bahasa Inggris yang tersedia di sekolahpun hanya berupa buku paket. Akibatnya, pembelajaran Bahasa Inggris di sekolah sangat tidak maksimal. Dibutuhkan sebuah media yang benar-benar dapat memberikan siswa keterampilan berbahasa Inggris sekaligus pengalaman belajar yang menyenangkan. Big book adalah jawaban dari permasalahan ini.

Big book adalah media ajar berbentuk buku berukuran besar berisi kata-kata atau kalimat-kalimat sederhana dan gambar-gambar yang mengilustrasikannya. USAID (2014) mendefinisikan big book sebagai media buku bacaan yang memiliki ukuran besar, dilengkapi 
tulisan dan gambar yang juga berukuran besar. Ukuran huruf yang besar bertujuan agar siswa sekolah dasar lebih mudah dalam belajar mengenal kata/kalimat dan sekaligus mengetahui maknanya. Biasanya, big book memiliki beberapa jenis ukuran seperti A3, A4, A5, atau seukuran surat kabar. Ukuran buku, tulisan, dan gambar yang besar memungkinkan adanya kegiatan membaca bersama (shared reading) sehingga ukuran big book yang digunakan seharusnya disesuaikan agar semua siswa dapat membacanya. Kelebihan big book adalah ukurannya yang besar, isinya yang menarik karena penuh warna, dan mudah untuk dibuat dengan proses yang sederhana dan biaya yang sedikit.

Ada beberapa manfaat penggunaan big book seperti yang dijelaskan oleh Nambiar (1991)). Big book dapat membantu siswa memahami jalannya cerita dengan lebih mudah dan lebih jelas. Selain itu, big book juga efektif dalam membuat siswa tetap fokus terhadap apa yang dibacanya. Big book juga dapat membantu siswa memahami isi cerita, sehingga siswa dapat membayangkan jika mereka menjadi tokoh dalam cerita tersebut. Dikarenakan sifat keterbaruannya, media big book dapat menarik minat dan antusiasme siswa dalam belajar.

Beberapa peneliti sebelumnya (Fahmi et al, 2010; Honchell \& Schulz, 2012; Mahayanti, 2017; Indrasari et al, 2018) pernah membahas tentang efektifitas big book dalam pembelajaran Bahasa Inggris bagi anak sekolah dasar. Hasilnya, big book terbukti efektif membantu siswa mengembangkan keterampilan berbahasanya yang mencakup keterampilan menyimak, berbicara, menulis, dan membaca. Atas dasar identifikasi masalah dan keberhasilan beberapa penelitian terdahulu, peneliti memutuskan untuk mengembangkan media ajar Bahasa Inggris big book bagi siswa kelas 4 - kelas 6 SD Negeri 6 Tambak Ukir.

\section{METODE PENELITIAN}

Penelitian ini adalah penelitian pengembangan (research and development). Tujuan dari penelitian ini adalah mengembangkan media ajar big book sebagai alternatif media ajar Bahasa Inggris bagi siswa kelas 4 - kelas 6 SD Negeri 6 Tambak Ukir. Prosedur dalam proses pengembangan ini mengadaptasi dari tahap-tahap R\&D Gall dkk (2003). Dalam penelitian ini, sepuluh tahapan R\&D Gall dkk disederhanakan menjadi empat tahap: (1) analisis kebutuhan, (2) pengembangan produk, (3) uji coba produk, dan (4) revisi produk.

1. Analisis kebutuhan 
Tahap pertama dalam penelitian ini adalah analisis kebutuhan. Tahap ini bertujuan untuk mendapatkan informasi yang jelas dan menyeluruh tentang permasalahan utama yang dihadapi. Hasil dari analisis kebutuhan menjadi dasar untuk pengembangan produk.

2. Pengembangan produk

Tahap ini mencakup proses pemetaan materi, pengembangan produk, dan validasi ahli.

Produk yang dihasilkan terdiri dari seperangkat big book yang terdiri dari sepuluh tema beserta petunjuk penggunaannya. Pengembangan produk terdiri dari beberapa tahapan kecil, yaitu proses penyusunan materi, proses pembuatan ilustrasi, proses penyusunan petunjuk penggunaan bagi guru. Pada tahap validasi ahli, dipilih empat orang ahli untuk menilai kualitas ketepatgunaan media yang dihasilkan. Empat ahli ini adalah satu ahli di bidang bahasa, satu ahli bidang teknologi pendidikan, satu orang ahli bidang pendidikan dasar, dan satu orang guru pengajar Bahasa Inggris di SD Negeri 6 Tambak Ukir. Data dari hasil validasi akan diambil menggunakan petunjuk evaluasi media ajar. Faktor-faktor yang dinilai mencakup aspek berikut: kelengkapan umum, metodologi, kesesuaian dengan siswa, kelengkapan fisik dan tambahan, tambahan bahan tambahan yang sesuai, isi, muatan perbendaharaan kata, dan tata bahasa.

3. Uji coba produk

Uji coba produk pada penelitian ini dilakukan dua kali, yaitu uji coba skala kecil dan uji coba lapangan. Uji coba skala kecil dilakukan setelah produk melalui tahap validasi dan revisi. Setelah itu, dilakukan uji coba lapangan dengan jumlah responden lebih besar dengan harapan produk benar-benar tepat guna bagi pemakainya. Kedua tahap uji coba ini dilakukan dengan siswa kelas 4- kelas 6 SD Negeri 6 Tambak Ukir.

Data dari hasil uji coba didapatkan melalui kuesioner dan akan dianalisis secara kuantitatif menggunakan Skala Likert, disajikan dalam bentuk prosentase dan deskriptif kualitatif. Rentang skala untuk kuesioner dan lembar pengamatan adalah 1-4 dengan keterangan 4 (sangat setuju), 3 (setuju), 2 (tidak setuju), dan 1 (sangat tidak setuju). Setelah itu, hasilnya dikonversi ke dalam bentuk persentase dengan rumus sebagai berikut:

$$
\text { Final score }=\frac{\text { Ltotal score }}{\text { Smaximum score }} \times 100
$$

\section{Revisi produk}

Revisi produk dilakukan berdasarkan hasil uji coba produk kedua yang didapat dari kuesioner, lembar pengamatan dan wawancara guru dan siswa. Revisi ini bersifat final, 
karena telah melalui beberapa tahap ilmiah (validasi ahli dan uji coba) sehingga hasil dari revisi akan menjadi masukan bagi perbaikan akhir produk sebelum tahap diseminasi.

Data dari lembar pengamatan akan dianalisis secara kuantitatif dan kualitatif. Variabel lembar pengamatan terdiri dari beberapa kriteria yang memiliki rentang 1-5 dengan detil sebagai berikut: 1 (tidak muncul di produk), 2 (muncul sebagian kecil di produk), 3 (muncul di beberapa bagian produk), 4 (muncul di sebagian besar bagian produk), dan 5 (muncul di hampir semua bagian produk). Produk tidak perlu direvisi atau butuh revisi sebagian kecil bila skor penilaian mencapai $80 \%$ dari total skor maksimal. Revisi produk akan dibuat berdasarkan pengkategorian hasil kuesioner menurut Hobri (2010) yang bisa dilihat pada Tabel 1

Tabel 1 Pengkategorian Hasil Kuesioner

\begin{tabular}{cccc}
\hline No & Skor Akhir & Kriteria & Deskripsi \\
\hline 1 & $>80 \%$ & Sangat baik & Tanpa revisi \\
\hline 2 & $66-79 \%$ & Baik & Revisi sebagian kecil \\
\hline 3 & $56-65 \%$ & Cukup & Revisi sebagian besar \\
\hline 4 & $\leq 56 \%$ & Kurang & Revisi total \\
\hline
\end{tabular}

Data dari wawancara akan dianalisis secara kualitatif. Revisi dibuat berdasarkan pendapat dan saran tambahan/masukan lebih dalam tentang produk. Diharapkan hasil akhir dari produk ini akan valid, efektif, dan praktis. Secara umum, prosedur penelitian ini dapat dilihat pada Gambar 1

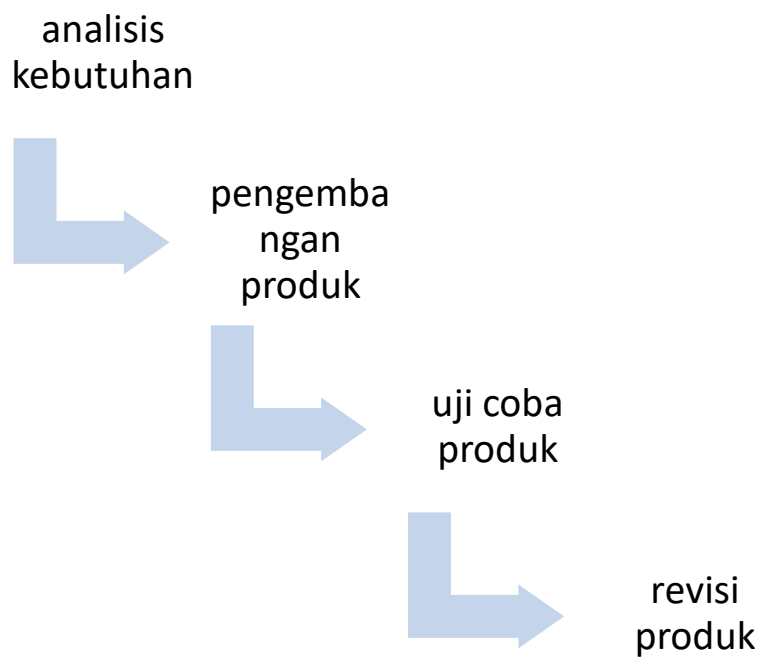

Gambar 1. Tahap Prosedur Penelitian 


\section{HASIL DAN PEMBAHASAN}

\section{Needs analysis (analisis kebutuhan).}

Hasil dari analisis kebutuhan menunjukkan bahwa proses pembelajaran Bahasa Inggris di SD Negeri 6 Tambak Ukir juga memiliki permasalahan yang kurang lebih sama dengan permasalahan di SD Negeri 1 Sumberargo. Siswa-siswa di SD Negeri 6 tambak Ukir jarang menerima pembelajaran Bahasa Inggris dikarenakan guru pengajar di sana tidak memiliki cukup keterampilan mengajar Bahasa Inggris. Selain itu, media pembelajaran di sekolah tersebut sangat terbatas sehingga tidak dapat membantu memaksimalkan proses belajar. Keterbatasan dana dan akses menuju sumber belajar yang lebih lengkap cukup sulit karena kondisi sosial ekonomi siswa dan sekolah yang kurang mendukung. Dikarenakan permasalahan-permasalahan tersebut, proses pembelajaran Bahasa Inggris di sekolah menjadi tidak maksimal sehingga keterampilan Bahasa Inggris siswa dapat dibilang rendah. Oleh karena itu, untuk membantu proses pembelajaran Bahasa Inggris, peneliti menawarkan untuk memebrikan media pembelajaran alternatif untuk mengajar Bahasa Inggris berupa big books karena sangat sesuai untuk digunakan oleh siswa SD belajar kosakata.

\section{Product development (pengembangan produk)}

Tahap pengembangan produk dibagi menjadi tiga tahap yaitu: pemetaan materi, pembuatan produk, dan validasi ahli.

a. Pemetaan materi

Materi yang dipakai dalam sepuluh big book yang dikembangkan adalah alphabet, animal, color, number, my body, my family, my school, playground, greeting and parting, dan introduction

b. Pembuatan produk

Pengembangan produk terdiri dari beberapa tahapan kecil, yaitu proses penyusunan materi, proses pembuatan ilustrasi, proses penyusunan petunjuk penggunaan bagi guru.

Pada tahap penyusunan materi, peneliti mengumpulkan bahan dari internet berupa gambar-gambar pendukung untuk disertakan dalam big book yang dikembangkan. Gambar-gambar yang dipilih adalah yang memiliki kualitas besar (di atas 700 px) agar saat dicetak tidak buram. Big book yang disusun terdiri dari materi ajar dan kegiatan siswa. Setelah materi dan kegiatan siswa selesai disusun, tahap selanjutnya adalah tahap ilustrasi. Tahap ilustrasi di sini mencakup ilustrasi layout 
halam buku dna ilustrasi sampul buku. Proses ilustrasi dilakukan secara digital menggunakan software online yaitu postermywall. Setelah itu, tahap terakhir dari proses pembuatan produk adalah penyusnan petunjuk kegiatan bagi guru. Petunjuk ini dibuat dengan tujuan memberikan alternatif cara mengajarkan kosakata kepada siswa menggunakan big book. Berikut big book yang telah dikembangkan.
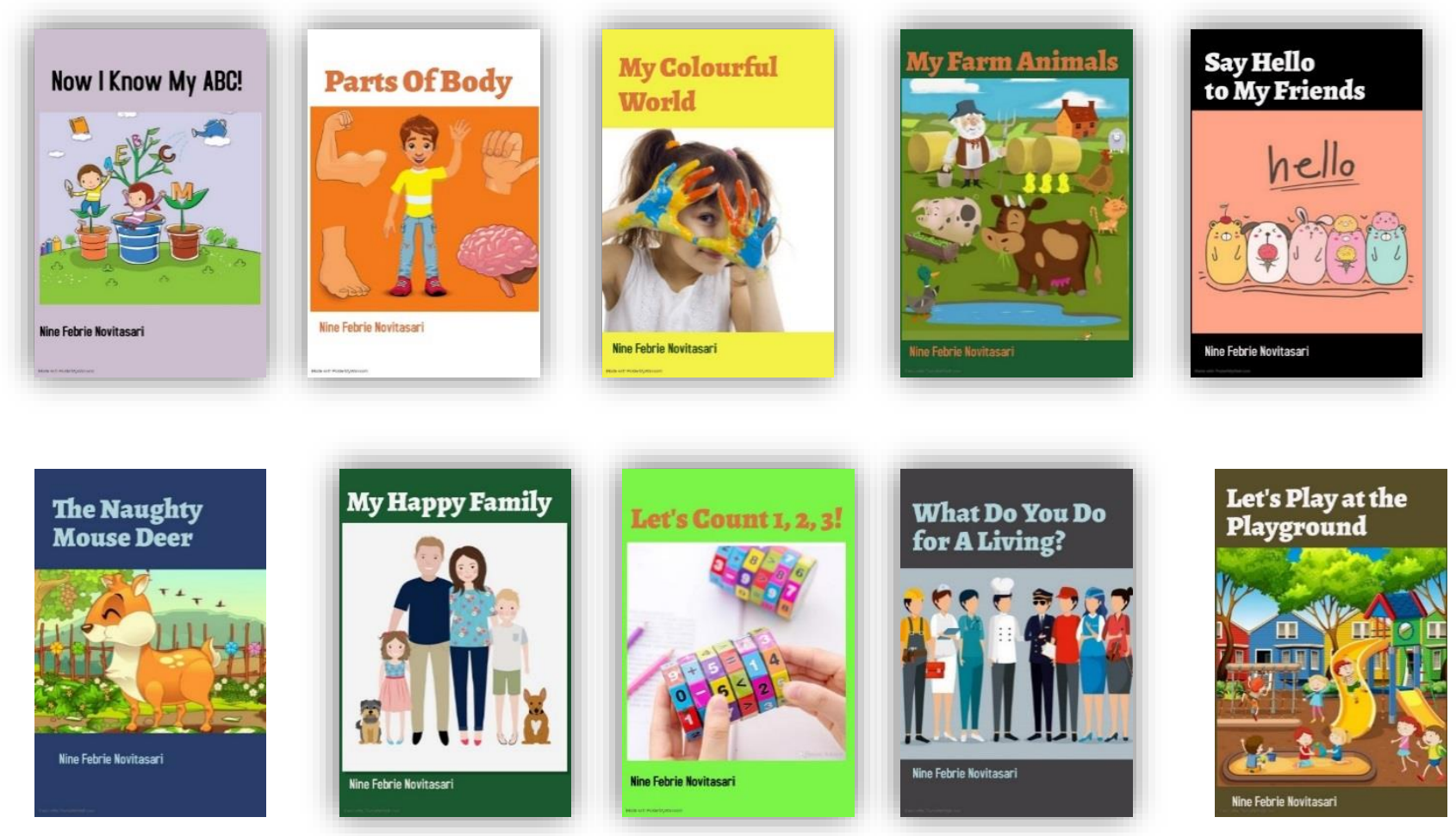

Gambar 2. Set Big Book

\section{Deskripsi produk:}

Big book ini dicetak digital dengan ukuran $31 \mathrm{~cm}$ x $70 \mathrm{~cm}$ pada kertas glossy paper. Buku ini tidak dijilid seperti buku biasa, namun dibuat dengan sistem ring di sisi buku sehingga mudah digunakan dan tidak cepat rusak.

c. Validasi ahli

Pada tahap validasi ahli, dipilih empat orang ahli untuk menilai kualitas ketepatgunaan media yang dihasilkan. Empat ahli ini adalah satu ahli di bidang bahasa, satu ahli bidang teknologi pendidikan, satu orang ahli di bidang pendidikan guru sekolah dasar, dan satu orang guru Bahasa Inggris.

Data dari hasil validasi akan diambil menggunakan petunjuk evaluasi media ajar.

Faktor- faktor yang dinilai mencakup aspek berikut: kelengkapan umum, metodologi, kesesuaian dengan siswa, kelengkapan fisik dan tambahan, tambahan bahan tambahan yang sesuai, isi, muatan perbendaharaan kata, dan tata bahasa. 


\section{d. Uji Coba Produk}

\section{Uji Coba I}

Uji coba I dilakukan pada tanggal 26 Oktober 2020. Uji coba ini dilakukan dengan siswa kelas 4 SD Negeri 6 Tambak Ukir. Big book yang diuji cobakan adalah big book dengan topik My Family. Berikut hasil dari uji coba I:

\section{Lembar observasi:}

Guru terlihat masih melalukukan penyesuaian terhadap media yang digunakan dan siswa dikarenakan ukuran buku yang besar dan proses pembelajaran tidak dilakukan di kelas seperti biasa. Selain itu, guru juga terlihat agak kesulitan menghandle siswa yang berebutan ingin memegang big book yang dipegangnya. Dari topik my family, tidak banyak permasalahan yang ditemukan. Permasalahan yang muncul hanyalah beberapa kesalahan dalam pengucapan kosakata. Guru terlihat beberapa kali berbicara menggunakan Bahasa Madura dikarenakan siswa tidak mengerti beberapa istilah dalam Bahasa Indonesia.

Kosa kata yang ada dalam buku sangat membantu siswa meningkatkan rentang kosa kata Bahasa Inggris mereka. Siswa lebih mudah memahami kosa kata dikarenakan adanya gambar yang berukuran besar dan berwarna-warni. Siswa terlihat tertarik dengan media yang digunakan. Hal ini nampak dari komentar-komentar yang diberikan saat mereka melihat gambar yang ada di big book.

\section{Wawancara:}

Guru menyatakan bahwa big book membantu mereka mengajar kosa kata Bahasa Inggris dikarenakan ukurannya yang besar dan tulisan serta gambar yang berwarna-warni. Selain itu, mereka merasa mendapat bahan ajar yang dapat melengkapi buku paket yang mereka pakai selama ini. Namun mereka ragu dalam mengajar pengucapan dikarenakan tidak melakukan banyak persiapan sebelumnya. 


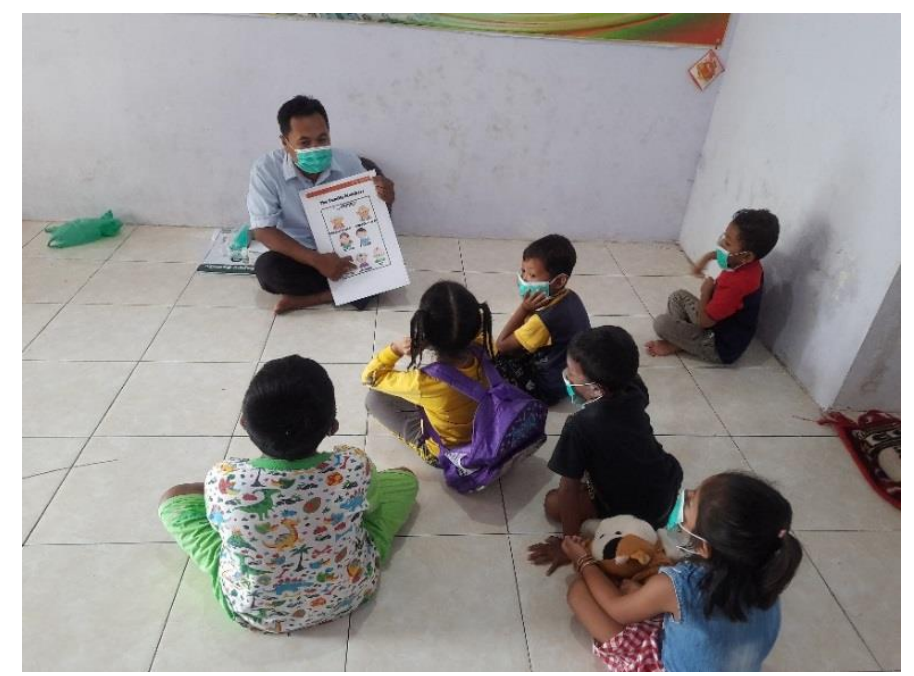

Gambar 1. Uji Coba 1

\section{Uji Coba 2}

Uji coba II dilakukan pada tanggal 27 Oktober 2020. Uji coba ini dilakukan dengan siswa kelas 5 SD Negeri 6 Tambak Ukir. Big book yang diuji cobakan adalah big book topik parts of body. Beriut hasil dari uji coba II:

\section{Lembar observasi:}

Guru sudah dapat menyesuaikan diri dengan media yang dipakainya. Guru sudah terlihat nyaman menggunakan big book. Hal ini terlihat dari gerakan tubuh guru yang terkadang menjelaskan sambil berdiri dan terkadang sambil duduk, menyesuaikan dengan kebutuhan. Guru tetap sesekali menjelaskan beberapa istilah menggunakan Bahasa Madura dikarenakan ada beberapa siswa yang tidak paham dengan kosakata Bahasa Indonesia. Permasalahan yang juga masih ditemui adalah kesalahan dalam peengucapan beberapa kosa kata seperti ear dan hair.

Siswa kelas 5 juga terlihat antusias saat belajar menggunakan big book. Hal ini terlihat dari siswa yang berebutan ingin melihat gambar di buku dari jarak lebih dekat. Selain itu, mereka juga antusias saat diminta menirukan guru mengucapkan beberapa kosa kata. Siswa juga terlihat membuka-buka buku setelah pembelajaran selesai. Namun ada satu bagian halaman yang ukuran gambarnya harus diperbesar yaitu di bagian bagian kepala. 


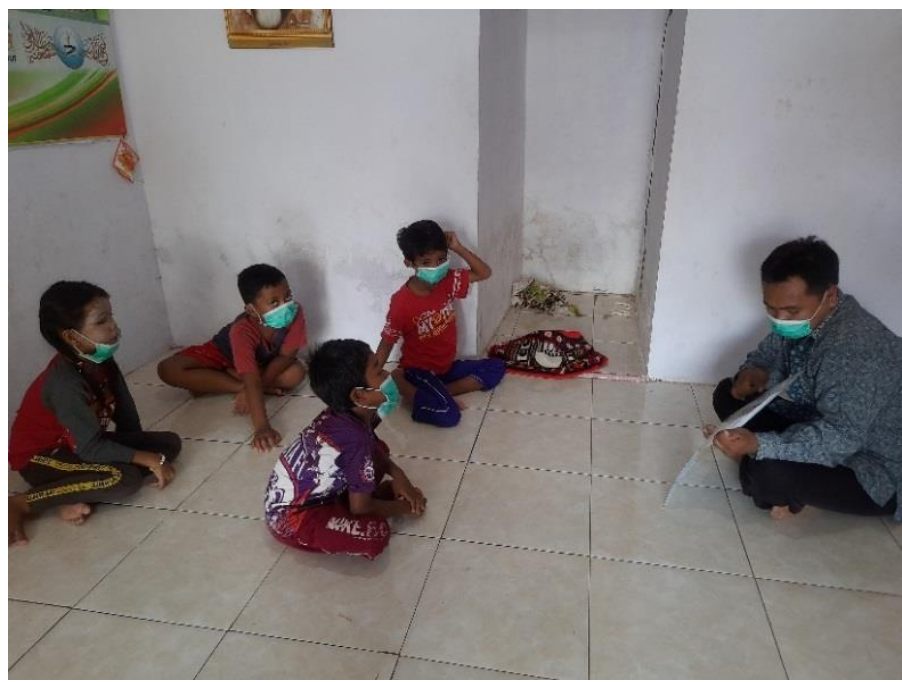

Gambar 3. Uji Coba 2

\section{Uji Coba 3}

Uji coba III dilakukan dengan siswa kelas 6 SD Negeri 6 Tambak Ukir pada tanggal 28 Oktober 2020. Big book yang digunakan adalah big book dengan topik playground. Berikut hasil dari uji coba III:

\section{Lembar observasi:}

Pada uji coba kali ini, topik yang dipakai adalah playground. Tujuannya adalah memperkenalkan jenis-jenis permainan di taman bermain yang belum pernah siswa SD Negeri 6 Tambak Ukir temui sebelumnya. Untuk mengajarkan topik ini, guru terlebih dahulu melakukan persiapan sehingga tidak salah dalam pengucapan kosa kata Bahasa Inggris karena teks yang digunakan adalah paragraf pendek, bukan lagi kata seperti di uji coba I dan uji coba II. Kesulitan yang dialami amsih tetap sama yaitu guru harus menjelaskan beberapa istilah dalam Bahasa Madura agar siswa lebih mudah memahami.

Siswa terlihat kesulitan saat diminta membaca teks pada buku dikarenakan mereka jarang sekali membaca teks dalam Bahasa Inggris. Selain itu, pembelajaran Bahasa Inggrispun jarang mereka dapat karena guru biasanya enggan mengajar dikarenakan terbatasnya sumber belajar dan keterampilan mengajar Bahasa Inggris yang dimiliki. Pada uji coba ini, guru meminta siswa bergantian membaca sehingga semua siswa mendapat kesempatan membaca. Siswa terlihat senanng belajar menggunakan big book. Walalu mereka membaca dengan kesulitan di sana-sini, namun mereka tetap tertawa saat mendapat masukan dari guru. 


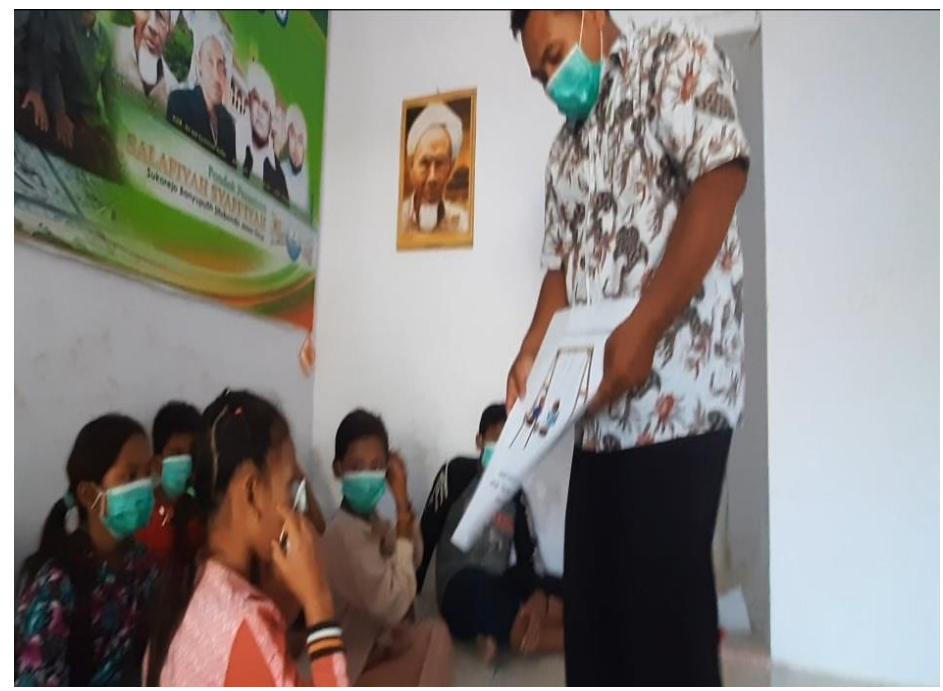

Gambar 4. Uji Coba 3

\section{KESIMPULAN}

Dari hasil validasi dan uji coba, dapat disimpulkan bahwa big book membantu guru SD Negeri 6 Tambak Ukir mengajar Bahasa Inggris dengan lebih mudah. Big book dapat membantu guru mengajarkan kosakata kepada siswa dengan media yang menarik karena ukuran tulisan dan gambar berwarna-warni pada big book. Siswa juga dapat belajar dengan proses yang menyenangkan dan lebih berkesan. Dengan demikian, big book yang dikembangkan memiliki sifat valid,efektif, dan efisien. Big book bersifat valid karena dikembangkan berdasarkan teori tentang pengembangan media, pembelajaran Bahasa Inggris bagi anak usia dini, dan ilmu bahasa; bersifat efektif karena dapat secara tepat memberikan apa yang dibutuhkan siswa yaitu media belajar, kegiatan yang menyenangkan, dan peningkatan keterampilan; bersifat praktis karena dapat memfasilitasi guru dan siswa dalam proses pembelajaran dengan mudah. Namun, walaupun demikian, guru tetap harus mempersiapkan diri sebelum mengajar menggunakan big book agar proses penyampaian materi lebih maksimal.

\section{DAFTAR PUSTAKA}

Afifah, R. (2012, October 25). Bahasa Inggris Bisa Masuk Muatan Lokal atau Ekskul. Jakarta Pusat. Retrieved from https://edukasi.kompas.com/read/2012/10/25/17475384/bahasa.inggris.bisa.masuk.mua tan.lokal.atau.ekskul 
Copland, F., Garton, S., \& Burns, A. (2014). Challenges in Teaching English to Young Learners: Global Perspectives and Local Realities. TESOL Quarterly, 48(4), 738-762. http://doi.org/10.1002/tesq.148

Fahmi, D. I., Suhartono, L., Arifin, Z., \& Program, E. E. (2015). Improving students' reading comprehension using big book. Tanjungpura University, 4(1), 1-11. Retrieved from http://jurnal.untan.ac.id/index.php/jpdpb/search/search?simpleQuery=dita+indah+fahmi \&searchField=authors

Gall, M. D., Gall, J. P., \& Borg, W. R. (2003). Educational Research: An Introduction (8th ed.). Boston: Pearson/Allyn \& Bacon.

Hartin. (2017). Pembelajaran Bahasa Inggris di Skeolah Dasar. Shautut Tarbiyah, 22(36), 118. http://doi.org/http://dx.doi.org/10.31332/str.v23i1.578

Hobri. (2010). Metodologi Penelitian Pengembangan. Jember: PENA Salsabila.

Honchell, B., \& Schulz, M. (2012). Engaging Young Readers with Text through Shared Reading Experiences, 4(3), 59-67.

Indrasari, A., Novita, D., \& Megawati, F. (2018). Big Book: Attractive Media for Teaching Vocabulary to Lower Class of Young Learners. JEES (Journal of English Educators Society), 3(2), 141. http://doi.org/10.21070/jees.v3i2.1572

Mahayanti, N. W. S., \& Asrina, N. K. A. (2017). The Implementation of Big Book as Media to Teach Reading Comprehension for the Sixth Grade Students of Elementary School. In 2nd International Conference on Innovative Research Across Disciplines (ICIRAD 2017) (Vol. 134, pp. 184-188). Atlantis Press. http://doi.org/10.2991/icirad17.2017.35

Maili, S. N. (2018). Bahasa Inggris Pada Sekolah Dasar : Jurnal Pendidika Unsika, 6(1), 2328. Retrieved from https://journal.unsika.ac.id/index.php/judika/article/view/1203

Moon, J. (2005). Teaching English to young learners: the challenges and the benefits, (October), 30-34. Retrieved from http://ventana.fl.unc.edu.ar/files/Material-BritishCouncil.pdf

Nambiar, M. K. (1991). Big Books for Little Readers: Works in the ESL Classroom Too. Retrieved from https://eric.ed.gov/?id=ED333736

Singleton, D. (2003) Critical Period or General Age Factor(s)? in García Mayo, M.P. \& García Lecumberri, M.L. (Eds) Age and the Acquisition of English as a Foreign Language. Clevedon: Multilingual Matters

USAID. (2014). Buku Sumber untuk Dosen LPTK: Pembelajaran Literasi Kelas Awal SD/MI di LPTK. Jakarta: USAID 